\title{
SPATIAL AND TEMPORAL VARIABILITY OF STANDARDIZED PRECIPITATION INDEX OVER INDOCHINA PENINSULA
}

\author{
T.M. VU, A.K. MISHRA*
}

Glenn Department of Civil Engineering, Clemson University, USA.

\begin{abstract}
Indochina Peninsula has abundant water resources; however, most of the rain falls during the wet season. An arid condition is quite pronounced throughout the dry season. The majority of population depends on the agriculture as the main source of livelihood income. It is, therefore, important to study the drought and wetness over the region because crops are vulnerable to extreme climatic conditions. We used gridded precipitation APHRODITE and Standardized Precipitation Index (SPI) to evaluate the spatial and temporal variability of drought and wetness over Indochina peninsula. Nonparametric Modified Mann-Kendall (MMK) trend test was applied to determine the SPI trends over this region. There is a decrease in precipitation over a large part of Indochina during winter (dry season) and an increasing pattern during summer (rainy season). The increasing trend of SPI indicates an increase in wet condition over most parts of Indochina Peninsula except for Red River Delta in Vietnam, central parts of Vietnam/Laos and western parts of Cambodia.
\end{abstract}

\section{Variabilidad espacial y temporal del Índice de Precipitación Estandarizada en la Península Indochina}

RESUMEN. La Península Indochina cuanta con abundantes recursos hídricos; sin embargo, la mayor parte de la lluvia cae durante la llamada estación húmeda y las condiciones áridas son bastante pronunciadas durante la estación seca. La mayor parte de la población depende de la agricultura como fuente principal de ingresos. Por ello, es importante estudiar la sequía y la humedad en la región porque los cultivos son vulnerables a condiciones climáticas extremas. Utilizamos precipitaciones en rejilla procedentes de la base de datos APHRODITE y el Índice de Precipitación Estandarizada (SPI) para evaluar la variabilidad espacial y temporal de la sequía y la humedad en la Península Indochina. Se aplicó el test de tendencias no paramétrico modificado de Mann-Kendall (MMK) para determinar las tendencias del SPI en la región. Se registra un descenso en la precipitación de gran parte de Indochina en invierno (estación seca) y un aumento durante el verano (estación húmeda). La tendencia creciente del SPI indica un aumento en las condiciones de humedad en la mayor parte de la Península Indochina, excepto para el delta del Río Rojo en Vietnam, partes centrales de Vietnam-Laos y sectores occidentales de Camboya. 
Key words: drought, wetness, trends, Indochina Peninsula.

Palabras clave: sequía, humedad, tendencias, Península Indochina.

Received 5 January 2016

Accepted 1 March 2016

*Corresponding author: A. K. Mishra, Glenn Department of Civil Engineering, Clemson University, Clemson SC 29634-0911, USA. E-mail: ashokm@g.clemson.edu

\section{Introduction}

Spatio-temporal drought analyzes are useful to improve water resources management (Mishra and Singh, 2010; Vicente-Serrano et al., 2012). It is expected that severe and widespread droughts likely to occur in the next 30-90 years over many land areas resulting from either decreased precipitation and/or increased evaporation (Dai, 2013). Further, it is expected that droughts are likely to set in quicker with higher intensity (Trenberth et al., 2014). The regional droughts can have a global impact on food supplies and undermine the economics and stability of governments (Sternberg, 2011). Droughts can significantly reduce agricultural crop yield, for example, reduction in crop yields in eastern and Western Europe (Ciais et al., 2005) and in East Asia (Zhang and Zhou, 2015).

Mann-Kendall (MK) test is commonly used for trend analysis of hydroclimatic variables as well as climate extremes, such as drought. Ganguli and Reddy (2014) evaluated drought trends in three meteorological subdivisions of western Indian using SPI and MK test and observed that there is an upward trend for SPI for the selected regions. Sousa et al. (2011) simulated drought and wetness by using Palmer Drought Severity Index (PDSI) and Self-Calibrated PDSI (scPDSI) for Mediterranean during the $20^{\text {th }}$ century. Paulo et al. (2012) compared multiple drought indices (SPEI, SPI, PDSI and MedPDSI) for Portugal and found that SPI and SPEI produced a similar result. However, PDSI and MedPDSI suggested more severe droughts with respect to SPI or SPEI. In China, Zhang et al. (2009) analyzed precipitation data from 42 stations over Pearl River Basin for 1960-2005 using SPI and Aridity Index. They indicated that Pearl River basin tends to be drier in the rainy season and wetter in winter.

Recently there have been few drought-related studies in Indochina Peninsula. $\mathrm{Vu}$ et al. (2014) examined drought conditions over seven sub-climatological regions in Vietnam using three drought indices: SPI, Aridity Index defined by de Martone (1926) and PED (Ped, 1975). They observed that drought frequently occurs during El Niño years and wetness conditions are associated with La Niña years in southern sub-regions of Vietnam. In another study, Vu et al. (2015) investigated Vietnam's Central highland drought condition using Regional Climate Model outputs (RCM). Miyan (2015) concluded that Laos and Cambodia are under the monsoon climatic zone, which has been suffering from increasing droughts due to delayed and changing distribution patterns of precipitation. Droughts being the most severe climatic hazards in 17 out of 20 provinces of Cambodia and are considered one of the most frequent and damaging disasters in 
Laos. The purpose of this discussion was to highlight that even though the Indochina Peninsula receives total annual precipitation of about $1500-2500 \mathrm{~mm}$, the drought seems to be frequent and common in many parts of the peninsula.

The majority of the populations in Indochina Peninsula depends on the agriculture as the main source of livelihood income. Among three countries, Vietnam is the world's third rice exporter as well as world's second coffee exporter. It is, therefore, important to investigate the drought and wetness over the region because crops are vulnerable to the extreme climatic condition. Most of the studies only investigated drought characteristics within a river basin; however, it is worth to study both dry and wet spell trends within the river basins for optimal use of available water resources. In this study, we investigated the spatial-temporal patterns of drought and wet spells using SPI for Indochina Peninsula. Models, data and methodology are introduced in section 2. Results are discussed in section 3 and conclusions are drawn in section 4.

\section{Model, data and methodology}

\subsection{Study area}

The Indochina Peninsula comprises of three developing countries: Laos, Cambodia and Vietnam (Fig. 1a). According to Koppen climate classification, major parts of Vietnam have tropical monsoon climate system (Am) while Laos has tropical wet and dry (Aw) climate. Cambodia has mixed climate pattern between Am and Aw types. Most of the higher elevated (above 500m) landscapes are located in most parts of Laos and northern, central highland of Vietnam, whereas flat topography is located in the most part of Cambodia and Mekong delta in Vietnam (Fig. 1a). Based on the Global Land Cover Characterization (GLCC) map by USGS (2015) (Fig. 1b), most of the croplands are clustered at river delta area in Vietnam (Red River Delta in the north and Mekong Delta in the south).

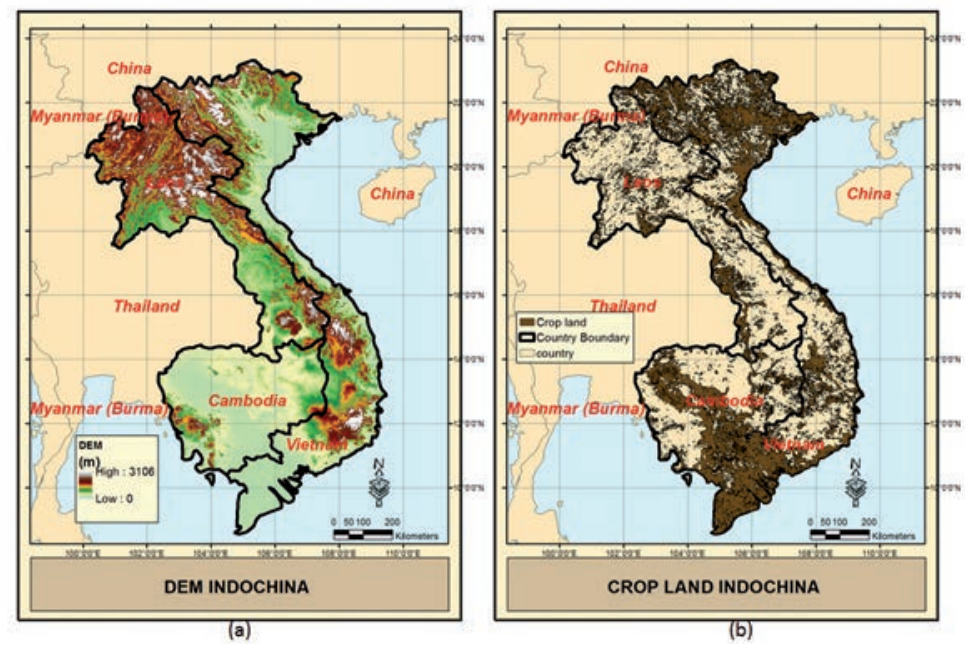

Figure 1. (a) SRTM Digital Elevation Model (DEM) (b) GLCC Crop land over Indochina Peninsula. 
The total annual precipitation in Indochina ranges from 1500-2500 mm (Fig. 2a). Most of the precipitations are concentrated in the center to southern Laos, center and Central Highland of Vietnam and coastal of Cambodia. The seasonal rainfall patterns over the three countries fluctuate greatly as shown in Figure 2 (b to e) for DecemberFebruary (DJF), March-May (MAM), June-August (JJA) and September-November (SON) respectively. The JJA season coincides with the southwest monsoon which dominants the rainfall distribution over the region. The inter-monsoon during SON shows significant wet area over the northern center of Vietnam as seen in Figure 2e. The winter season (DJF) and inter-monsoon (MAM) are particularly dry over the peninsula (Fig. 2b, c).

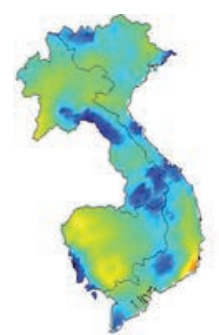

(a)

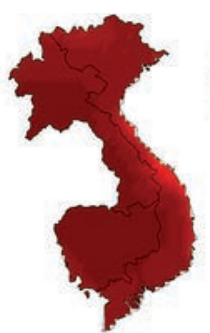

(b)

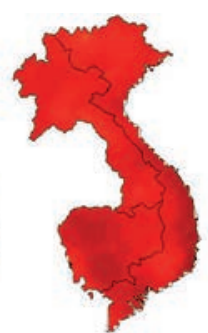

(c)

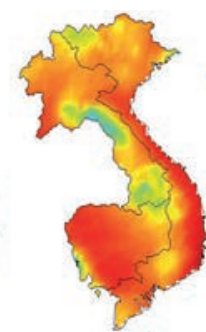

(d)

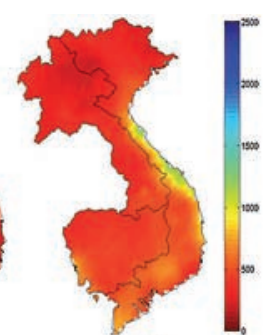

(e)

Figure 2. Total Annual and Seasonal Precipitation Average over Indochina Peninsula: (a) Annual (b) DJF (c) MAM (d) JJA (e) SON. Unit: mm.

\subsection{Data}

We used the gridded observational dataset 'The Asian Precipitation Highly Resolved Observational Data Integration Towards Evaluation of water resources data (APHRODITE),' referred to as 'APH' in this paper. The APH data was developed by the Research Institute for Humanity and Nature and Meteorological Research Institute of Japan. This dataset provides rainfall and surface temperature information at $0.25^{\circ}$ over the Asia on a daily time scale for 1951-2007. More information can be found at the web link at: http://www.chikyu.ac.jp/precip/ and from Yatagai et al. (2012). APH dataset has been used in many previous studies over this region in Raghavan et al. (2014, 2015), Vu et al. $(2012,2015)$.

\subsection{Standardized Precipitation Index (SPI)}

The SPI was first introduced by McKee et al. (1993) to quantify dry and wet spells by analyzing historical monthly precipitation. The SPI can be calculated for any location based on the long-term precipitation record. Steps involved in calculating SPI are: (a) first a long-term precipitation record is fitted to a probability distribution, (b) which is then transformed to a normal distribution so that the mean SPI for the location and desired period is zero (McKee et al., 1993). Several studies applied SPI for droughtrelated studies, for example, drought forecasting (Mishra and Desai, 2005a and 2006); spatio-temporal analysis (Mishra and Desai, 2005b) and probabilistic characterizations (Mishra et al., 2011). The drought/wetness classification based on SPI adapted from Mc Kee et al. (1993) is shown in Table 1. 
Table 1. Drought classification [adopted from McKee et al. (1993)].

\begin{tabular}{|c|c|}
\hline SPI values & Drought category \\
\hline 0 to -0.99 & Mild drought \\
\hline-1.00 to -1.49 & Moderate drought \\
\hline-1.50 to -1.99 & Severe drought \\
\hline$<-2$ & Extreme drought \\
\hline
\end{tabular}

\subsection{Trend test analysis}

\subsubsection{Modified Mann-Kendall test}

Mann-Kendall (MK) test is widely used for trend analysis in hydrology and climate related studies. For example, application of MK test to precipitation (Partal and Kahya, 2006; Mishra et al., 2009; Tabari and Talaee, 2011b; Gocic and Trajovic, 2013); temperature (Tabari and Talaee, 2011a; Gocic and Trajovic, 2013); flood and low flows (Douglas et al., 2000; Mishra et al., 2010) and streamflow (Birsan et al., 2006; Novotny and Stefan, 2007).

As Mann-Kendall test is a non-parametric test, it does not require the data to be distributed normally. However, the SPI values are calculated using a moving window concept, hence, it has a serial correlation effect and it may not be directly used in MK test. Therefore, to overcome this limitation, we used modified MK (MMK) test suggested by Hamed and Rao (1998). The positive values of $\mathrm{Z}$ indicate increasing trends (upward trend) while negative $Z$ indicate decreasing trends (downward trend). When testing either increasing or decreasing monotonic trends at the $\alpha$ significance level, the null hypothesis was rejected for an absolute value of $Z$ greater than $Z_{1-\alpha / 2}$ that is obtained from the standard normal cumulative distribution tables (Tabari and Talaee, 2011b; Gocic and Trajovic, 2013). In this paper, at a statistical significance level of $\alpha=0.05$, the trend detected by the $\mathrm{Z}$ value is tabulated in Table 2 .

Tabla 2. Trend detected for $Z$ value at significant level $\alpha=0.05$.

\begin{tabular}{|c|c|}
\hline $\mathbf{Z}$ & Trend detected \\
\hline $\mathrm{Z}>1.96$ & Significant increase \\
\hline $0<\mathrm{Z} \leq 1.96$ & Insignificant increase \\
\hline$-1.96 \leq \mathrm{Z}<0$ & Insignificant decrease \\
\hline $\mathrm{Z}<-1.96$ & Significant decrease \\
\hline
\end{tabular}

\subsubsection{Sen's slope estimator}

The slope (change per unit time) can be estimated by using a simple non-parametric procedure developed by Sen (1968). The slope estimates of $\mathrm{N}$ pairs of data are first computed by

$$
Q_{i}=\frac{x_{j}-x_{k}}{j-k} \quad \text { for } \mathrm{i}=1, \ldots, \mathrm{N}
$$


where $x_{j}$ and $x_{k}$ are data values at time $j$ and $k(j>k)$. The median of these $N$ values of $Q_{i}$ is a Sen's estimator of slope (Partal and Kahya, 2006). Sen's slope has been used in many other studies (Vu et al., 2014, Tabari 2011a, b, Paulo et al., 2012) to quantify the slope associated with climate variables. In this study Sen's slope estimator was applied to find the slope for Precipitation over Indochina Peninsula.

\subsection{Climate Index}

ENSO (El Niño Southern Oscillation) is a coupled ocean-atmosphere phenomenon associated with changes in the sea surface temperature in the tropical Pacific and major shifts in the Intertropical Convergence Zone over the Pacific Ocean (Khedun et al., 2014). The Southern Oscillation Index (SOI) and the Sea Surface Temperature (SST) are the two most widely used indicators of ENSO. Nino 3.4 index is a widely used index of ENSO activity. It is calculated by averaging the Kaplan Extended Sea Surface Temperature (SST) anomalies (Kaplan et al., 1998) in the region comprising $5^{\circ} \mathrm{S}-5^{\circ} \mathrm{N}$ and $170^{\circ} \mathrm{W}-120^{\circ} \mathrm{W}$ and the time series data for Niño 3.4 index regions are available on a monthly time scale (Mishra et al., 2011). In this study Niño 3.4 index data was collected from NOAA (http://www.esrl.noaa.gov) for the study period in term of monthly anomaly SST. The correlations between SPI with lag 3 months of Niño 3.4 index were computed in annual and season scale.

\section{Results}

\subsection{Precipitation trend}

The precipitation trend results are shown in Fig. 3. MK trend tests are depicted as $\mathrm{Z}$ values with a significant level of $95 \%$ confident. In Fig. 3, significant increasing in precipitation is displayed in blue color and the non-significant increasing trend is denoted in light blue color. There is a non-significant increase in precipitation observed in most of Indochina Peninsula with a portion of south of Vietnam witness a significant increasing trend (Fig. 3a). There is significant decreasing trend in rainfall in winter (DJF) season in several parts of Laos (Fig. 3b) and significant increasing trend in MAM and JJA seasons in the mountainous area in southern Laos and Central Highland Vietnam (Fig. 3c, d). Wherever there is significant increase/decreasing trend, Sen's slope shows corresponding high increasing/decreasing rate of rainfall over the corresponding spatial units. The highest increase in precipitation rate is observed in summer (JJA) season at $1 \mathrm{~mm} / \mathrm{month}$ in the southern of Laos (Fig. 3i). The highest decreasing rate of rainfall is observed in southern Laos and northern Cambodia of about 0.2-0.4 mm/month during inter-monsoon (SON) season (Fig. 3j). Significant decreasing in precipitation during the dry season (DJF) is seen in Fig. 3b at southern Laos and Central Highland Vietnam. In contrast, significant increasing in precipitation trend for the same location is detected for the rainy season (JJA) as displayed in Fig. 3d. Wetter during wet season and drier during dry season would affect the agriculture system badly in the area. 

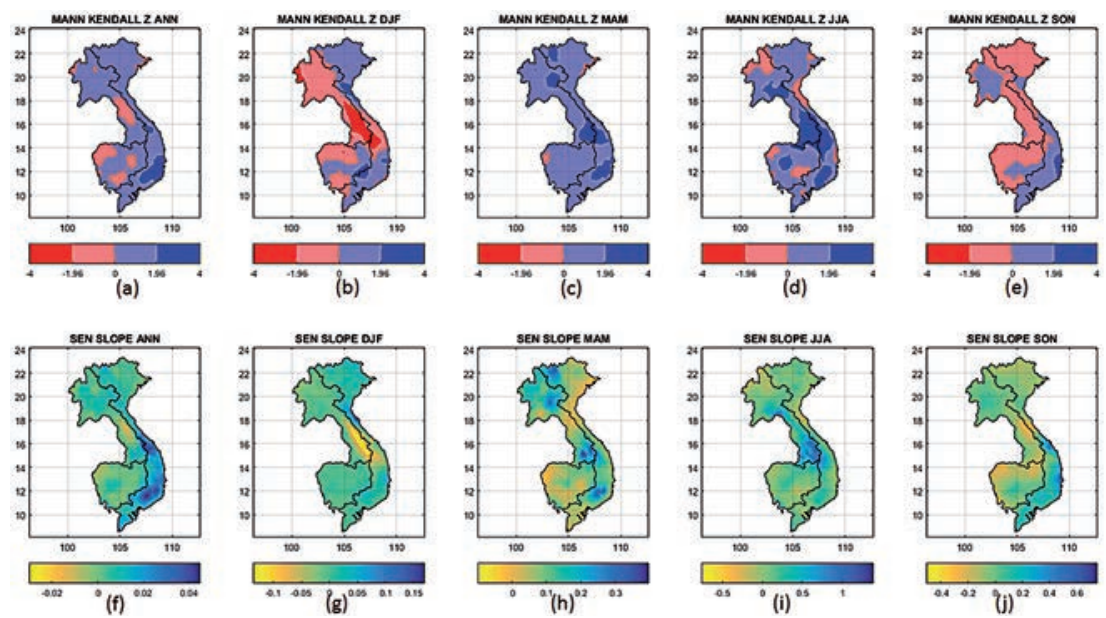

Figure 3. Precipitation Mann Kendall trend test Z: (a) Annual (b) DJF (c) MAM (d) JJA (e) SON and Sen's slope estimator: $(f)$ Annual $(g)$ DJF (h) MAM (i) JJA (j) SON over Indochina Peninsula. Unit: mm/month.

\subsection{SPI trend}

The SPI was computed spatially for Indochina Peninsula domain using APH dataset from 1952-2007. The MMK trend test was applied to evaluate SPI trends in Indochina Peninsula (Fig. 4). Based on annual and seasonal scales, there is a significant increase in SPI, which indicates an increasing trend in wetness condition in most of the Indochina region (Fig. 4a-e), especially in northern/southern Laos, most parts from center to southern Vietnam and center part of Cambodia. However, there are three regions with significant decreasing SPI trend, which indicates an increase in drought condition. These are located in western Cambodia (near the border of Thailand), the northeastern part of Vietnam (Red river delta) and the center region of Vietnam/Laos. The decreasing trends were observed for the rainy season (JJA) and dry season (DJF). The results infer that these regions are having the potential impact of moderate to extreme droughts. SPI in winter (DJF) season shows a significant increasing trend for southern Laos and Central Highland Vietnam.

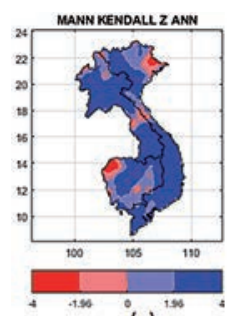

(a)

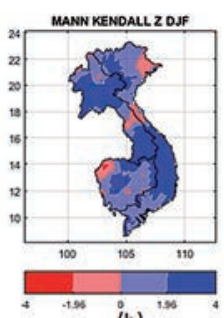

(b)

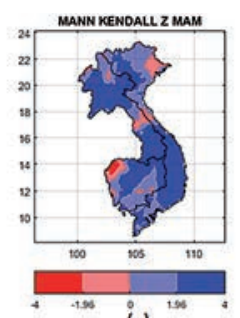

(c)

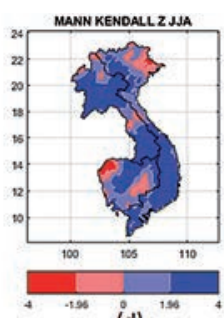

(d)

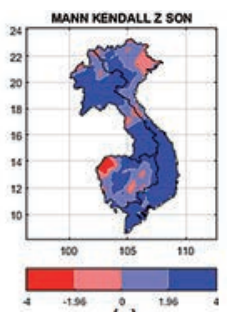

(e)

Figure 4. SPI Modified Mann Kendall trend test Z: (a) Annual (b) DJF (c) MAM (d) JJA (e) SON over Indochina Peninsula. 


\subsection{SPI trend over Red river delta}

As noted from the previous section, northeastern Vietnam and western Cambodia are expecting decreasing in SPI trend for the 1952-2007 period. It infers that drought condition is impacting the Red river delta of Vietnam. In this section, we focus on the SPI trend of northeastern Vietnam. Fig. 5 ( $a$ and b) shows areal average SPI time series for Red river delta for two periods: 20 years (1952-1972) and 35 years (1972-2007). During the first 20-year period, there is an overall increase in SPI trend for the region (increasing in a wet condition) as seen in Figure 5a. However, during the recent 35-year period, the regional SPI depicts a decreasing trend (Figure 5b), indicating an increase in drought events. Figure $5 \mathrm{c}$ displays the percentage of area under drought for first 20 year period, calculated by using a threshold of less than negative 1.5 (severe to extreme drought) at all grid boxes over Red River Delta. There are multiyear severe droughts affecting almost $100 \%$ of the area (e.g., 1953) and this could affect the agriculture system of the whole Red River Delta. As increasing in wetness condition from 19601965 (Fig. 5a), the drought area for this period reduces significantly. There is a slightly increasing trend in the percentage of drought area based on the recent 35-year period over the region (Fig. 5d).

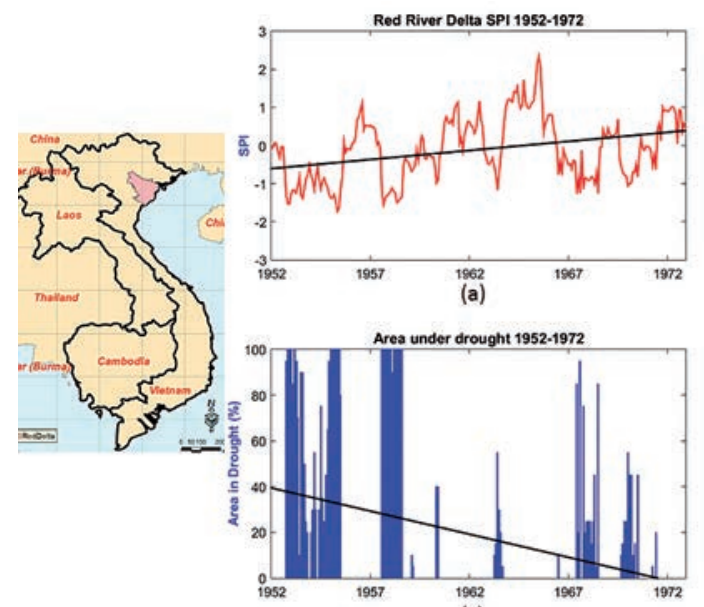

(c)
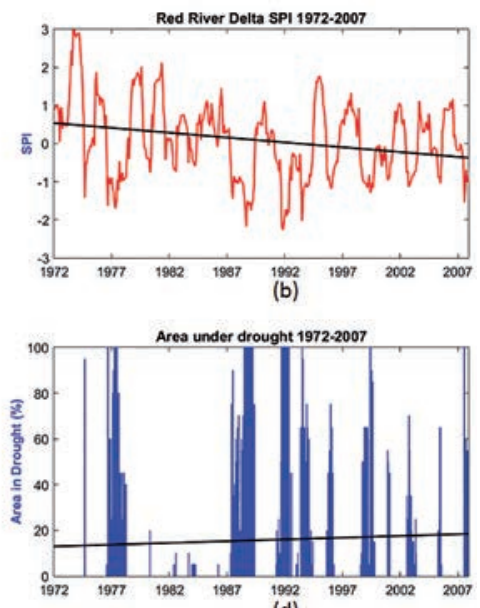

(d)

Figure 5. (a) Areal average SPI Time series from 1952-1972 (b) Areal average SPI Time series from 1972-2007 (c) Percentage of area in drought for Red River Delta 1952-1972 (d) Percentage of area in drought for Red River Delta 1972-2007.

\subsection{Correlation with ENSO}

Drought and wetness conditions in Vietnam are related to ENSO events, such as drought associated with El Niño and wetness correlated with La Niña (Vu et al., 2014). The spatial correlation map between 3 months lagged SPI and Niño 3.4 index is displayed in Figure 6 at annual and seasonal time scale at $95 \%$ confidence interval. The 
correlation coefficient ranges from -0.4 to 0.4. This range is considered to be reasonable for correlation between SST and local precipitation (Evan et al., 1998; Manatsa et al., 2008; Zhang and Zhou, 2015). As seen in annual and most of the seasonal plots (Fig. $6 a, b, c d)$, the correlations between SPI and Niño 3.4 index are about negative 0.3 to negative 0.4 for the coastal region of Vietnam and Cambodia. It indicates that increase in SST condition (El Niño phase) will lead to a decrease in SPI (i.e., drought condition increase). In contrast, wetness condition increases during La Niña phase. The dry season (DJF) in Laos has a positive correlation of 0.4 (Fig. 6b), which indicates that under El Niño phase, there might be an increasing in wetness condition over this area. Summer season (JJA), which coincides with rainy season, has the highest correlation in both spatial and temporal scale (Fig. 6d). This finding is important and will be studied in detail in our future research.

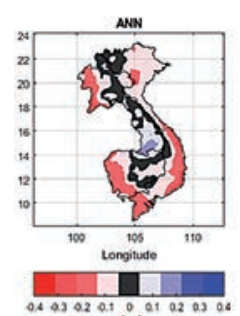

(a)

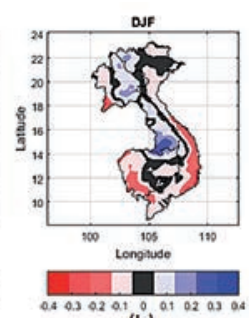

(b)

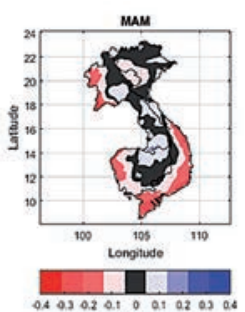

(c)

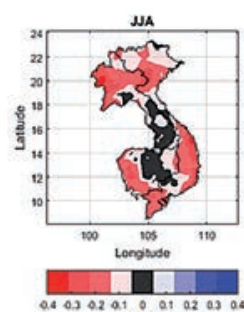

(d)

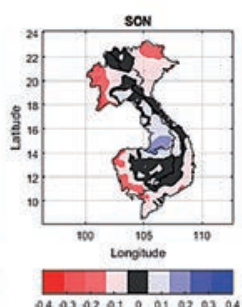

(e)

Figure 6. Correlation of lag 3 month SPI with SST Niño 3.4 index over Indochina Peninsula. (a) Annual (b) DJF (c) MAM (d) JJA (e) SON at 95\% confidence interval.

\section{Conclusions}

The following conclusions are drawn from this study:

1. Despite the significant decreasing trend in precipitation during the dry season (DJF) and non-significant decreasing trend during inter-monsoon (SON) season, increase in wet trends are observed over most parts of Indochina, except Red River Delta in Vietnam, the center of Vietnam/Laos and western part of Cambodia.

2. The highest increasing rate in precipitation is observed during the rainy season (JJA) in the central part of Indochina Peninsula. It infers the flooding potential over this area.

3. A detailed study of Red River Delta based on two time periods: 1952-1972 (20 years) and 1972-2007 (35 years) shows that there is an increasing wetness condition during the first 20 years and on the other hand, the last 35 year period indicates an increase toward arid condition leading to an increase in the percentage of drought areas over that region. 
4. Spatial correlation between lag 3 month SPI and Niño 3.4 index indicates that SPI over Indochina Peninsula correlates with ENSO at most of the coastal parts of Vietnam and Cambodia.

\section{References}

Birsan, M.V., Molnar, P., Burlando, P., Pfaundler, M. 2005. Streamflow trends in Switzerland. Journal of Hydrology 314, 312-329.

Ciais, P., Reichstein, M., Viovy, N., Granier, A., Ogee, J., Allard, V., Aubinet, M., Buchmann, N., Bernhofer, C., Carrara, A., Chevallier, F., De Noblet, N., Friend, A.D., Friedlingstein, P., Grunwald, T., Heinesch, B., Keronen, P., Knohl, A., Krinner, G., Loustau, D., Manca, G., Matteucci, G., Miglietta, F., Ourcival, J.M., Papale, D., Pilegaard, K., Rambal, S., Seufert, G., Soussana, J.F., Sanz, M.J., Schulze, E.D., Vesala, T., Valentini, R. 2005 Europe-wide reduction in primary productivity caused by the heat and drought in 2003 . Nature 437,529 533.

Dai, A. 2013. Increasing drought under global warming in observations and models. Nature Climate Change 3, 52-58.

De Martonne, E. 1926. Une nouvelle fonction climatologique: L'Indice d'aridite. La Meteorologie 2, 449-458.

Douglas, E.M., Vogel, R.M., Kroll, C.N. 2000. Trends in floods and low flows in the United States: impact of spatial correlation. Journal of Hydrology 240, 90-105.

Evans, M.N., Fairbanks, R.G., Rubenstone, J.L. 1998. A proxy index of ENSO teleconnections. Nature 394, 732-733.

Ganguli, P., Reddy, M.J. 2014. Evaluation of trends and multivariate frequency analysis of droughts in three meteorological subdivisions of western India. International Journal of Climatology 34, 911-928.

Gocic, M., Trajovic, S.P. 2013. Analysis of precipitation and drought data in Serbia over the period 1980-2010. Journal of Hydrology 494 (3-4), 32-42.

Hamed, K.H., Rao, A.R. 1998. A modified Mann-Kendall trend test for auto-correlated data. Journal of Hydrology 204, 182-196.

Kaplan, A., Cane, M.A., Kushnir,Y. Clement, A.C., Blumenthal, M.B., Rajagopalan, B. 1998. Analyses of global sea surface temperature 1856-1991. Journal of Geophysical Research 103 (C9), 18,567-18,589.

Kendall, M.G. 1975. Rank Correlation Methods. 4th edition. Charles Griffin, London.

Khedun, C.P., Mishra, A.K., Singh, V.P., Giardino, J.R. 2014. A copula-based precipitation forecasting model: Investigating the interdecadal modulation of ENSO's impacts on monthly precipitation. Water Resources Research 50, 580-600.

Manatsa, D., Chingombea, W., Matarirab, C.H. 2008. The impact of the positive Indian Ocean dipole on Zimbabwe droughts. International Journal of Climatology 28, 2011-2029.

Mann, H.B. 1945. Nonparametric tests against trend. Econometrica 13, 245-259.

McKee, T.B., Doesken, N.J., Kleist, J. 1993. The relationship of drought frequency and duration to time scales. In Proc. 8th Conf. on Applied Climatology, American Meteorological Society, Boston, Massachusetts, pp. 179-184.

Mishra, A.K., Desai, V.R. 2005a. Drought Forecasting using Stochastic Models. Stochastic Environmental Research and Risk Assessment 19, 326-339.

Mishra, A.K., Desai, V.R. 2005b. Spatial and temporal drought analysis in the Kansabati River Basin, India. International Journal of River Basin Management 3 (1), 31-41. 
Mishra, A.K., Desai, V.R. 2006. Drought forecasting using feed forward recursive neural network. Ecological modeling 198, 127-138.

Mishra, A.K., Singh, V.P. 2010. A review of drought concepts. Journal of Hydrology 391 (1-2), 202-216.

Mishra, A.K., Özger, M., Singh, V.P. 2009. Trend and persistence of precipitation under climate change scenarios. Hydrological processes 23 (16), 2345-2357.

Mishra, A.K., Singh, V.P., Özger, M. 2010. Seasonal streamflow extremes in Texas River basins: uncertainty, trends and teleconnections. Journal of Geophysical Research-Atmosphere 116, D08108.

Mishra, A.K., Singh, V.P., Özger, M. 2011. Seasonal streamflow extremes in Texas river basins: Uncertainty, trends, and teleconnections. Journal of Geophysical Research 116, D08108.

Miyan, M.A. 2015. Droughts in Asian Least Developd Countries: Vulnerability and sustainability. Weather and Climate Extremes 7, 8-23.

Novotny, E.V., Stefan, H.G. 2007. Stream flow in Minnesota: Indicator of climate change. Journal of Hydrology 334 (3-4), 319-333.

Partal, T., Kahya, E. 2006. Trend analysis in Turkish precipitation data. Hydrological Processes 20, 2011-2026.

Paulo, A.A., Rosa, P.D., Pereira, L.S. 2012. Climate trends and behaviour of drought indices based on precipitation and evapotranspiration in Portugal. Natural Hazards and Earth System Sciences 12, 1481-1491.

Ped, D.A. 1975. On indicators of droughts and wet conditions (in Russian). Proceeding USSR Hydrometeorological Center 156, 19-39.

Raghavan, S.V., Vu, M.T., Liong, S.Y. 2014. Impact of climate change on future stream flow in the Dakbla river basin. Journal of Hydroinformatics 16 (1), 231-244.

Raghavan, S.V., Vu, M.T., Liong, S.Y. 2015. Regional climate simulations over Vietnam using the WRF model. Theoretical Applied Climatology. Doi: 10.1007/s00704-015-1557-0.

Sen, P.K. 1968. Estimates of the regression coefficient based on Kendall's tau. Journal of the American Statistical Association 63 (324), 1379-1389.

Sousa, P.M., Trigo, R.M., Aizpurua, P., Nieto, R., Gimeno, L., García-Herrera, R. 2011. Trends and extremes of drought indices throughout the 20th century in the Mediterranean. Natural Hazards and Earth System Sciences 11, 33-51.

Sternberg, T. 2011. Regional drought has a global impact. Nature 472, 169.

Tabari, H., Talaee, H.P. 2011a. Analysis of trends in temperature data in arid and semi-arid regions of Iran. Global and Planetary Change 79 (1-2), 1-10.

Tabari, H., Talaee, H.P. 2011b. Temporal variability of precipitation over Iran: 1966-2005. Journal of Hydrology 396 (3-4), 313-320.

Trenberth, K.E., Dai, A., Van der Schrier, G., Jones, P.D., Barichivich, J., Briffa, K.R., Sheffield, J. 2014. Global warming and changes in drought. Nature Climate Change 4, 17-22.

USGS. Global Land Cover Characterization Program. Available at: http://edc2.usgs.gov/glcc/ euras_int.php (last access: 02/2015).

Vicente-Serrano, S.M., Beguería, S., Lorenzo-Lacruz, J., Camarero, J.J., López-Moreno, J.I., Azorín-Molina, C., Revuelto, J., Morán-Tejeda, E., Sánchez-Lorenzo, A. 2012. Performance of drought indices for ecological, agricultural, and hydrological applications. Earth Interaction $16,1-27$.

Vu, M.T., Raghavan, S.V., Liong, S.Y. 2014. SWAT use of gridded observations for simulating runoff - a Vietnam river basin study. Hydrology and Earth System Sciences 16, 2801-2811.

Vu, M.T., Raghavan, V.S., Pham, D.M., Liong, S.Y. 2015. Investigating drought over the Central Highland, Vietnam, using regional climate models. Journal of Hydrology 526, 265-273. 
Vu, T.H., Ngo, D.T., Phan, V.T. 2014. Evolution of meteorological drought characteristics in Vietnam during the 1961-2007 period. Theoretical and Applied Climatology 118 (3), 367-375.

Xie, P., Yatagai, A., Chen, M., Hayasaka, T., Fukushima, Y., Liu, C., Yang, S., 2007. A Gauge-Based Analysis of Daily Precipitation over East Asia. Journal of Hydrometeorology 8, 607-627.

Yatagai, A., Kamiguchi, K., Arakawa, O., Hamada, A., Yasutomi, N., Kitoh, A. 2012. APHRODITE: Constructing a Long-term Daily Gridded Precipitation Dataset for Asia based on a Dense Network of Rain Gauges. Bulletin of American Meteorological Society 93, 1401-1415.

Zhang, L., Zhou, T. 2015. Drought over Asia: A Review. Journal of Climate 28, 3375-3399.

Zhang, Q., Xu, X.Y., Zhang, Z.X. 2009. Observed changes of drought/wetness episodes in the Pearl River basin, China, using the standardized precipitation index and aridity index. Theoretical and Applied Climatology 98, 89-99. 